\title{
Liberalism after Communitarianism
}

\author{
Charles Blattberg \\ Professor of Political Philosophy \\ Université de Montréal
}

\section{Introduction}

Since the beginning of the modern age, there have been political thinkers who complain about its over-emphasis on the individual. Others have raised concerns about the dangers associated with too much community. One version of this dispute is reflected in the 'liberal-communitarian debate', which arose within anglophone political philosophy during the 1980s. The liberals were led by John Rawls, along with Ronald Dworkin, Thomas Nagel, and T.M. Scanlon. And the communitarian critique of their work was advanced by, among others, Alasdair MacIntyre, Michael Sandel, Charles Taylor, and Michael Walzer. As we might expect, since the publication of the writings of both groups, some have seen fit to declare one side or other of the debate the victor. But we should assume that none of the leading participants saw their exchanges in such merely competitive terms. After all, serious thinkers know that theirs is a higher - because ultimately philosophical - calling.

We can understand the debate as arising primarily around Rawls' A Theory of Justice (1999; originally published in 1971). The book defends what he considers to be the key principles of liberalism. To Rawls, we should endorse that political order which matches what rational citizens would freely choose from 'the original position'. This is the perspective attained by stepping behind a hypothetical 'veil of ignorance', which conceals individuals' knowledge of their capacities or social position. By imagining ourselves behind such a veil, we are said to be able to deliberate in a truly representative manner, and so 'regard the human situation not only from all social but also from all temporal points of view' (Rawls 1999: 514). In this way, we can formulate principles of justice that provide the basis for a universally acceptable social contract.

Such a universalist approach, however, is just one of two routes to the liberalism Rawls offers in the book. He also thinks we can reach a conception of justice through a process of 'reflective equilibrium'. It requires starting from - and remaining connected to - actual liberal societies. By conceiving of their practices as reflecting considered judgments that can serve as

\footnotetext{
* Chapter 11 of Gerard Delanty and Stephen Turner, eds., Handbook of Contemporary Social and Political Theory (New York: Routledge, 2021, 2nd ed.).
} 
provisional fixed points, Rawls believes we can reformulate them in a more systematically unified manner. Indeed, by tacking back and forth, from practice to theory and back again, he thinks we will eventually arrive at the very same principles of justice derived from the original position.

Communitarians tended to focus on Rawls' universalist case for liberalism, critiquing it along two basic lines. First, they argued that the original position is simply impossible. To achieve the necessary detachment, all of our ends would have to be matters of choice. But this relies on an “atomist" (Taylor 1985) or "unencumbered" (Sandel 1998: 90, 172, 178-79; 2005) conception of the self, one that is simply not ontologically accurate. Second, communitarians held that, even if attainable, such detachment would be undesirable. This is because it is compatible with only individualistic ends, and so would undermine those social practices that need to be carried out in common with others - from friendship and family to broader forms of community. One reason for this is that universalist principles are simply too abstract to move ordinary citizens.

Rawls responded with 'Justice as Fairness: Political not Metaphysical' (1985), a paper largely included in the first chapter of his Political Liberalism (1993). In this work, Rawls downplays the original position, characterizing it as no more than an illustrative device, and emphasizes reflective equilibrium instead (now also called 'Kantian constructivism'). Rawls also stipulates that this approach never assumes we should, or even could, choose our life plans ex nihilo. We may simply evaluate some of our ends in the light of others, treating none as anything more than provisional fixed points. He also denies asserting any particular conception of the self. To Rawls, since such questions are ontological, hence metaphysical, they fall outside the scope of his strictly 'political' approach. This is why it needs to be distinguished from those based on 'comprehensive' worldviews.

Since we achieve reflective equilibrium through a more systematic formulation of the principles already underpinning liberal democratic regimes' public political cultures, Rawls believes that the vision of justice derived from it can be upheld by the members of many different communities and ways of life. After all, they already coexist more or less reasonably within these regimes. So Rawls takes such a shared political ideal to represent a unified 'overlapping consensus', one detachable from those parts of citizens' lives not relevant to politics. The latter are what are captured by comprehensive views that, as we might expect, will remain divergent.

This approach has led some to describe Rawls and other 'political liberals' (e.g. Larmore 1996) as having taking a 'hermeneutical' turn (e.g. Richardson 1990: 22). And the systematic 
reformulating they favour is indeed a form of interpretation. However, it is too 'theoretical' to align with the contemporary hermeneutics associated with figures such as Hans-Georg Gadamer (1989). Rawls aims to reach a stable resting point: a theory of justice capable of guiding political practice. But hermeneutical interpretation is usually portrayed as ongoing - as always on 'the way' (to borrow an expression from Gadamer's teacher, Martin Heidegger [2008]; see also Gadamer 1981: 105).

So while hermeneutical social critics also aim for better interpretations of political justice, they don't seek fixed and systematic principles. Hermeneutics entails a thoroughly contextual form of judgment that is 'practical' rather than 'theoretical' (Dreyfus 2014). We might even say that its practitioners should avoid any talk of principles (Dancy 2004). This also helps clarify why we shouldn't conflate the exchange of hermeneutical interpretations with the dialogues envisioned by deliberative democrats. To the latter, interlocutors must conform to pre-conceived theoretical frameworks if they are to make contributions to 'public reason' (Rawls) or 'communicative action' (Jürgen Habermas).

In time, the debate between liberals and communitarians both dissolved and ramified. The dissolution accompanied a growing recognition that most of the 'communitarians' actually reject the label (except, notably, Daniel Bell 1993). Many even consider themselves liberals of a sort, including Taylor and Walzer. And as Taylor (1985: 195) along with Sandel (1998: 149) have acknowledged, the debate's liberals have themselves come to embrace their own conceptions of community (e.g. Dworkin 2002: ch. 5). In fact, since then, four distinct-but-related new strands of liberalism have emerged. Shaped by other recent foci of contemporary anglophone political philosophy - including deliberative democracy, human and animal rights, postcolonialism, and national, global, and environmental justice - we might refer to them collectively as 'liberalism after communitarianism'.

\section{Liberalism as an Ideology}

Whether or not they consider their theories of justice as universally applicable, liberals such as Rawls have consistently viewed them as providing a neutral framework: a conception of right within which citizens may pursue their different and often rival conceptions of the good. This accords with such popular expressions as 'liberal democracy' as well as their implication that liberalism is more than 'another sectarian doctrine' (Rawls 1985: 246) - more than a mere ideology 
on par with those such as conservatism, socialism, feminism, environmentalism, and so on. This is why Dworkin (2006: 7), for example, has been able to unselfconsciously propose that US liberals and conservatives confront one another politically on an explicitly liberal common ground.

However, those who conceive of liberalism as an ideological 'fighting creed' (Taylor 1995b: 249) generally oppose the separation of the right from the good. So rather than neutrality, they favour what is sometimes called a 'perfectionist' state. They likewise reject the thoroughly pejorative, Marxist-inspired notion of ideology for which it is nothing more than a mask for material or other interests. To Michael Freeden (1996: 3), for instance, an ideology is simply a way of 'political thinking, loose or rigid, deliberate or unintended, through which individuals and groups construct an understanding of the political world they, or those who preoccupy their thoughts, inhabit, and then act on that understanding'.

Freeden is the leading student of liberalism as an ideology today. His morphological approach focuses on the evolving meanings and configurations of political concepts, sensitizing him to liberalism's many forms. Noting the variety of ways that its core, adjacent, and peripheral concepts have been identified, related, and decontested, his work underscores how liberalism's meanings have differed not only between countries but also throughout history (Freeden 1996, 2005, 2008). So while he is surely aware of how the American variant, the one that attracted most communitarian criticisms, has served to inspire many beleaguered liberals around the world, he has nevertheless also complained about its relatively inward-looking, ahistorical, narrow, and impoverished qualities. This has been accompanied by his compelling accounts of liberalisms that avoid such depoliticization and over-emphasis on individual rights, and so make more room for shared concerns with well-being and social solidarity

However, Freeden's approach is also overly 'analytical', by which I mean insufficiently holistic. His accounts of ideologies in general, and liberalism in particular, mainly consist of 'assembling' - of moving 'from concepts to ideologies', as one of his chapter titles puts it (Freeden 1996: ch. 2). But hermeneutics teaches that we should always begin the other way around, that is, with the whole rather than with its parts. Given normative concepts' ongoing connection with broader ideological backgrounds, properly conceptualizing an ideology's parts means that we should also continually strive to take account of the whole.

Freeden does occasionally begin writing about a political thinker by generally characterizing their ideology as a whole. But even in such cases, after moving on to consider associated individual 
concepts, he rarely brings that broader doctrinal context to bear. And more often than not, he opens with a concept-by-concept account of the ideology's core. So while Freeden's studies sensitively capture how adjacent concepts can shape each others' meanings, both logically and culturally, he neglects the parallel relationships that connect them to the broader doctrine. For example, he refers to how L.T. Hobhouse sums-up his liberalism:

The heart of liberalism is the understanding that progress is not a matter of mechanical contrivance, but of the liberation of living spiritual energy. Good mechanism is that which provides the channels wherein such energy can flow unimpeded, unobstructed by its own exuberance of output, vivifying the social structure, expanding and ennobling the life of mind (Hobhouse 1964: 73; quoted in Freeden 2005: 25).

Yet while noting that this summation 'informs' Hobhouse's particular understandings of 'the core liberal concepts of liberty, rationality, progress, individuality, sociability, a common good, limited and responsible power' (2005: 25-26), Freeden has little more to say about the matter.

Moreover, while he decries the ostensive neutrality of liberalism's American variant, he assumes ideologies should be studied without judging them as better or worse. But can we really understand an ideology without considering how it measures up to any broader norms the community might share, e.g. of justice or truth? Contemporary hermeneutics says no. It is certainly often possible to describe without prescribing, as when saying 'This is a chair'. But that is simply infeasible when it comes to moral and political concepts: they necessarily implicate our selfunderstandings, raising questions about nothing less than who we are (Taylor 1988).

In that sense, Freeden's approach takes him to the opposite extreme from Marxists. For he simply does not have much to say about the limitations of ideological thinking (Freeden 2009 being a notable exception). Indeed, he seems far from impressed by longstanding complaints that such fighting creeds tend to encourage dogmatic attitudes (e.g. Namier 1955: 5-7) - or that ideological inflexibility often accompanies overly adversarial responses to political conflict. I include here responding with force rather than dialogue, of course, but also being unduly adversarial in exchanges that stop short of violence. Ideologies may indeed help guide us through high-stakes social encounters. But they likewise tend to get in the way when, for instance, we hope 
to address conflict with open-minded conversation rather than with negotiation (Blattberg 2009a). More on this below.

\section{Liberalism in the Face of Diversity: Autonomy}

First, however, I want to discuss another major development since the liberal-communitarian debate. It has seen liberals strive to more sensitively account for Western societies' significant diversity, as well as the identity-related challenges this can entail. Focusing particularly on the place of minority populations, many recent liberal thinkers have taken one of two approaches.

There is the defence of a perfectionist liberalism - a liberalism, again, of the good and not merely the right. Such views gather around a particular conception of individual freedom. Needless to say, this core liberal value has had many rival interpretations, advanced under labels including 'negative freedom', 'self-ownership', 'experiments in living', 'authenticity', and 'nondomination'. Perfectionist liberals tend to favour 'autonomy', however.

Of course, this term is also central to Immanuel Kant's account, according to which individual liberty should be equated with morality as a whole, understood as consisting of selfdetermined principles. To many perfectionist liberals, by contrast, 'autonomy' expresses individuals' freedom to choose between different ways of life. Understood in this way, the idea plays a minor if significant role in Walzer's liberalism. For him, the 'autonomous person .... [is] the ideal subject of the theory of justice', since citizens should be able to choose to participate in the various institutions, associations, or distributive spheres present in modern society (Walzer 1983: 279; 2007a). However, autonomy as the ability to choose is front and centre in the liberalisms of Joseph Raz and Will Kymlicka. ${ }^{1}$

They consider their approaches especially appropriate for multicultural societies, helping address a shortcoming that attracted communitarian critique. Although older conceptions of liberalism purport to be neutral among different cultural groups, Raz and Kymlicka argue that they are often 'implicitly tilted towards the needs, interests, and identities of the majority group; and this creates a range of burdens, barriers, stigmatizations, and exclusions for members of minority

\footnotetext{
${ }^{1}$ That said, Kymlicka is not as comfortable with the idea of perfectionism as Raz - and this despite his willingness (Kymlicka 2002: 277n6) to countenance 'short-term state intervention designed to introduce people to valuable ways of life', i.e. to conceptions of the good.
} 
groups' (Kymlicka and Norman 2000: 4). Such older perspectives, in fact, tend to see ethnocultural or national minorities as potential threats to the liberal polity's unity.

Raz and Kymlicka's alternative gives priority to a greater respect for diversity. Not that citizens' motivations need to be in any sense altruistic: as Raz puts it, for instance, 'the conditions of autonomy require an environment rich in possibilities' (Raz 1994: 107; see also Raz 1986: chs. 14-15; Kymlicka 1995: chs. 5, 8; and Kymlicka 2002: ch. 6). Otherwise put, if freedom is indeed a matter of choosing, then there must be an adequate range of options to choose from. Raz, and Kymlicka after him, therefore argue that ethnic or national minorities should be seen as making an invaluable contribution by broadening cultural options for people - so long, that is, as they do so within a framework that respects autonomy.

But is autonomy really the best way to conceive of individual liberty? Raz recommends it as an ideal particularly suited to the often-changing conditions of contemporary society (1986: 370). And Kymlicka sees it as virtually entailed by both modernization and globalization (2002: 369). However, this emphasis on choice also points towards one of modern society's least-attractive features: consumerism. So the association makes it hard not to question Raz's claim that it is through our choices that we best define our morality. To Raz, autonomy requires 'morally acceptable options' (1986: 378). One might object, though, that we often don't really conceive of a moral action as optional, since we simply could not choose otherwise and remain true to ourselves (a way of talking that, admittedly, betrays sympathy for the conception of individual liberty as 'authenticity').

The danger of understanding individual freedom as making choices, then, is trivialization. As Taylor has written of the word 'choice', it 'occludes almost everything important: the sacrificed alternatives in a dilemmatic situation, and the real moral weight of the situation' (2007: 479). The idea of 'options' is equally problematic, since it suggests a number of independently distinct items to choose from. At least according to accounts of perception derived from hermeneutical phenomenology (e.g. Merleau-Ponty 2012), moral reality is once again usually much more holistic. For one thing, it tends to be a matter of shades and degrees. For another, which choices we interpret as possible, and how, remain intimately related to us as a whole; after all, they express the values that help constitute our identities.

To Kymlicka, however, the capacity to weigh such moral possibilities is central. We can assess and criticize our moral choices' personal significance, he argues, only because 'we can 
"stand apart" or "step back" from our current ends, and question their value to us' (Kymlicka 2002: 215 , though see $278 \mathrm{n} 2)$. Yet is such disengagement really necessary for criticism?

\section{Liberalism in the Face of Diversity: Value Pluralism}

To value pluralists such as Isaiah Berlin, Stuart Hampshire, John Kekes, and Bernard Williams, the answer would be 'no'. They not only reject neutralist forms of liberalism, but their conception of the diversity of values also leads them to a view of practical reason, and so criticism, that wholly avoids disengagement, not to mention the belief that liberalism relies on a foundationalist conception of autonomy. Each approach is, in its own way, guilty of monism.

To these pluralists, moral and political conflicts frequently arise from the existence of incommensurable values, which are often at odds. And their incommensurability means that we cannot respond to such conflicts by turning to an abstract, systematic theory for guidance, whether neutralist or perfectionist. Such theories assume that all values have been commensurated, in the loose sense of interlocked within a unified system. But this is simply impossible without seriously distorting them, and by extension the different ways of life they express. Moreover, such theories also serve to 'shelter' certain values from the vicissitudes of everyday politics, placing them beyond compromise. Yet this tends only to make the conflicts involving them worse.

So value pluralists emphasize instead how people in conflict should be willing to negotiate in good faith. This means being open to making concessions, since that's often the only way to reach a balanced accommodation. Not only may we not share the same values - or interpretations of them - as those with whom we find ourselves in conflict, but we should also consider their values as genuine. After all, it's not their 'fault' they were raised differently than we were. In consequence, because they, too, are moral agents deserving a certain minimum of respect, we ought to tolerate them to some degree and thereby make at least some concessions for reasons other than that we feel forced to do so.

But what concessions, exactly? And how much should we concede? Value pluralists may be said to turn here for guidance to ideologies, which call on us to assign different values different weights. As we might expect, however, there is far from a consensus between them over which specific ideology, and so which particular ranking of values, deserves our support. This is why, crudely put, liberals such as Berlin and Williams would have us favour individual liberty, socialists such as Hampshire equality, and conservatives such as Kekes order through controlled change. 
Regardless of the value they happen to cherish most, however, all value pluralists agree that we cannot award it a trumping status, since no value is absolute. This is especially evident when conflicts arise between the values favoured by one's preferred ideology. So we can understand why all pluralist liberals can be said to agree with William Galston (1991: 195) that 'liberalism is a basket of ideals that inevitably come into conflict with one another if a serious effort is made to realize any one of them fully, let alone all of them simultaneously'.

Evidently, this liberalism is quite different from Raz or Kymlicka's: its fulcrum is toleration, not autonomy. While Raz claims to subscribe to value pluralism, he does so not because he sees it as true to the moral reality, so much as a way of serving autonomy. For he argues that toleration should be subservient to autonomy (1986: 407). As for Kymlicka, he conceives of autonomy and toleration as but 'two sides of the same coin', which is why he, too, will not countenance any compromise of the former in favour of the latter (2002: 231, 245).

Liberals who affirm value pluralism cannot accept this, and not only because of their great emphasis on toleration. There's also a deeper, philosophical reason. I already mentioned how recognizing a plurality of conflicting and incommensurable values leads them to reject systematic theories of justice in favour of negotiation. But this also implies that deciding on which ideology to favour for guidance cannot itself be a philosophical matter. The reason is that there is simply no way to derive moral guidance from the mere recognition of disunity, from the belief that we live in a world 'where ends collide' (Berlin 2013a: 195; and see Blattberg 2009a). In consequence, value pluralists turn instead to interpretations of the political culture in which they find themselves, 'the general pattern of life in which we believe' (Berlin 2002: 47; see also 42, and Berlin 2013b: 19).

Since it makes no sense to try and go from pluralism-in-itself to any particular ideology, Berlin has thus come to assert that 'Pluralism and liberalism are not the same or even overlapping concepts. There are liberal theories which are not pluralistic. I believe in both liberalism and pluralism, but they are not logically connected' (Berlin and Jahanbegloo 1991: 44; see also Berlin and Williams 1994: 308-309). Of course, Berlin's earlier writings have been read as providing evidence he supported the opposite position (e.g. Gray 2013: ch. 6), referring, for instance, to his claim that there exists a more-or-less unbreachable minimal private sphere of individual liberty. But is this sufficient to support a full-blown liberalism? Consider what we might identify as the question of 'How much liberty?' Berlin's reply is 'that which a man cannot give up without 
offending against the essence of his human nature'. However, doesn't this contrast sharply with the 'extreme demand for liberty' made by the fathers of liberalism, they who, evidently, 'want more than this minimum' (Berlin 2002: 173, 207)?

In any case, my main objection to this liberalism - indeed, to any value pluralist politics - is with the priority it places on negotiation; more specifically, with the way this emphasis often precludes the non-adversarial form of dialogue that is conversation. Rather than negotiating accommodations, conversational interlocutors cooperate in an attempt to integrate their conflicting values. The goal is thus something more than negotiation's zero-sum compromising, which balances conflicting values against one another. It is because participants in a conversation assume that their values are parts of a shared whole - the common good - that they may attempt a reconciliation of their conflict rather than a mere accommodation. Indeed, by striving for synergistic solutions, they can learn from one another - not about the most effective ways to put pressure on their adversaries, nor about how much they should be compromising, but about how to realize and further develop all of the values at stake.

This approach is especially vital when it comes to 'the politics of recognition', when conflicts have arisen over a group's wish to be recognized (usually by the state) for its distinctiveness within the polity. Recognition is a matter of knowledge, and so truth - something the German and French words for it, Anerkennung and reconnaissance, make especially clear. And since one either learns that something is true or does not - this being not the kind of thing that could be up for negotiation - conversation is the only form of dialogue that has the potential to bring such recognition.

Despite this, the politics of recognition is often presented as consisting of 'struggles' over 'demands' (e.g. Honneth 1995; Taylor 1995b: 225). The problem here is that conversation is only viable when conflicts are considered 'oppositional' but not 'adversarial' (Blattberg 2009b). After all, anyone hoping to converse with someone who is willing only to negotiate will quickly realize that conversation is impossible. Moreover, on a deeper level, because adversarial conceptions of conflict also generally assume some 'clash' or 'collision' of values, and because this results from a view of values as separate, independently distinct things, any assumption that those involved could share some larger whole will be undermined - and along with it any hope for conversational progress. 
So we should not be surprised by the many references in value pluralist writings to dirty hands and even tragedy (e.g. Berlin 2002: 200, 214; Hampshire 1989: 170-77; Williams 1981). When politics consists at best of making compromises, everyone must expect to lose something of value. Lacking a conception of the whole, value pluralists thus end up with a politics from which there is nothing to gain, much less to learn (Blattberg 2000).

\section{Fearful Liberalism}

Communitarians, Judith N. Shklar has complained, fail to appreciate the extent to which liberalism, as a matter of practice, has provided them with the luxury of worrying about the nature of the self. And these worries are, in any case, distractions at best; at worst, they can lead people to do real damage to those very same practices (Shklar 1998a: 17-18).

So we can see why Shklar came to defend what she calls a 'liberalism of fear'. Like almost all liberalisms, it gives the greatest possible weight to individual liberty. But hers is unique in being based on neither a theory of justice, nor an architectonic conception of personal freedom as autonomy, nor a pluralist-driven affirmation of toleration. Rather, it starts from the claim that 'cruelty is an absolute evil' and that the 'willful inflicting of physical pain on a weaker being in order to cause anguish and fear' is a fundamental infringement on liberty (Shklar 1998a: 5; 1984: 8). Liberals, Shklar thus believes, should recognize that the key division within the political world is the one between the weak and the strong, and that only by protecting the former from the latter can we be said to 'put cruelty first' (Shklar 1998a: 9, 19).

As mentioned, she doesn't derive this norm from a moral theory (Shklar 1998a: 12). So she recognizes that we cannot hope to uphold it consistently, as monists assume, since any attempt to do so will encounter contradictions. This means we should reject those readings of her work that portray Shklar as a monist (e.g. Fives 2020). But nor should we go along with those who consider her a pluralist (e.g. Misra 2016: 78, 80,87). Because where pluralists assume that there exists no singular, all-embracing summum, Shklar's belief that cruelty is the summum malum is, as we've seen, central to her liberalism (Shklar 1998a: 10-11).

Paradoxically, then, her approach can be understood to combine elements of both monism and pluralism, forming what we might call a 'pluramonism'. Indeed, Shklar has taken note of Walzer's adoption of a similar metaphysics: she describes his work as 'self-divided' (Shklar 1998b: 379), most likely referencing his paradoxical claim that morality sometimes requires us to 
override justice, even though this means 'dirtying' our hands (Walzer 2007b). ${ }^{2}$ But Shklar seems to overlook her own pluramonism. For example, she appears to see nothing contradictory about, on the one hand, issuing a monistic call on individuals to 'submit to a single system of law equally applicable to all', since 'it is only the modern state, with its unified legal system, that provides the necessary framework within which voluntary associations can form', while, on the other hand, confidently declaring that 'the enemy of any pluralism is monopoly and the domination it yields' (Shklar 1998b: 385, 382).

In fact, Shklar's pluramonism was there from the beginning. In 1964, one of her first books attempts 'to account for the difficulties which the morality of justice faces in a morally pluralistic world' - 'morality of justice' is clearly monist, while 'morally pluralistic world' is, of course, pluralist (Shklar 1986: 123). The book likewise tells us both that 'human institutions survive because most of us can live quite comfortably with wholly contradictory beliefs', and that we sometimes face a 'difficult choice among a variety of equally valid obligations' (Shklar 1986: x, 73). So when Shklar (1984: ch. 2) argues in a later work against considering hypocrisy as the worst political vice, her analysis sometimes seems to veer into apology. This is only to be expected, since while hypocrisy is deemed unnecessary by the pluralist and intolerable by the monist, to the pluramonist it will tend to appear as both unavoidable and tolerable.

Why has Shklar's liberalism of fear attracted such interest now, decades after her original essay's publication? One reason must surely be that people have been drawn to how her profound concern with cruelty has led her to be especially mindful about the ongoing effects of slavery in America, for instance, or about refugees, women, and other disproportionately vulnerable groups. While some have always been struck by the urgent need to right these injustices, today's increased sensitivity to suffering has meant that they have been joined by others - all of whom, together, can be expected to view political thinking that makes security a central concern as very compelling. Richard Rorty, who has endorsed Shklar's definition of liberalism (Rorty 1989: xv), foreshadowed this development when he praised the significant reduction in the psychological humiliation of the weak that attends it, although he has simultaneously rightly decried the failure to do much about the steady increase in economic insecurity that has accompanied it (Rorty 1998: 79-85). Others, however, have worried that too great a concern with security in whatever form may be counter-

\footnotetext{
${ }^{2}$ For more on Walzer's pluramonism, see Blattberg (2018).
} 
productive. One reaction to the ideas of Thomas Hobbes, for instance, has been to note that the 'search for perfect security ... defeats its own ends. Playing for safety is the most dangerous way to live' (Lindsay 1950: xxvii). Could the relative minimalism of Shklar's approach mean that her liberalism is ultimately less effective at meeting its own strictly mitigating ends than more ambitious forms of it? I, for one, think so.

\section{Conclusion}

Like all ideologies, liberalism will continue to evolve. Identifying how it should do so will, needless to say, remain a central challenge for liberals of every sort. When it comes to their extramural struggles, though, it seems to me that, before confronting others who support different ideologies in an adversarial way, liberals should try to engage them in conversation. And doing so properly means listening to what they have to say rather than to some preconceived doctrine such as an ideology - including the ideology of liberalism. So what I am suggesting is that, if liberals are genuinely to approach their fellow citizens with open minds whenever there's a conflict, then they must set aside their liberalism, if only for a time. For that is what the common good requires. Perhaps, then, this is communitarianism's greatest lesson. 


\section{REFERENCES}

Bell, D. (1993) Communitarianism and Its Critics, Oxford: Oxford University Press.

Berlin, I., and R. Jahanbegloo (1991) Conversations with Isaiah Berlin, London: Peter Halban.

----- and B. Williams (1994) 'Pluralism and Liberalism: A Reply', Political Studies, 62 (2) 306309.

----- (2002) 'Two Concepts of Liberty', in Liberty: Incorporating Four Essays on Liberty, H. Hardy (ed.) Oxford: Oxford University Press.

----- (2013a) 'Does Political Theory Still Exist?' in Concepts and Categories: Philosophical Essays, H. Hardy (ed.) Princeton: Princeton University Press, 2nd ed.

----- (2013b) 'The Pursuit of the Ideal' in The Crooked Timber of Humanity: Chapters in the History of Ideas, H. Hardy (ed.) Princeton: Princeton University Press, 2nd ed.

Blattberg, C. (2000) From Pluralist to Patriotic Politics: Putting Practice First, Oxford: Oxford University Press.

----- (2009a) 'Political Philosophies and Political Ideologies', in Patriotic Elaborations: Essays in Practical Philosophy, Montreal: McGill-Queen's University Press.

----- (2009b) 'Opponents vs. Adversaries in Plato's Phaedo', in Patriotic Elaborations: Essays in Practical Philosophy, Montreal: McGill-Queen's University Press.

----- (2018) ‘Dirty Hands: The One and the Many' The Monist, 101 (2) 150-169.

Dancy, J. (2004) Ethics without Principles, Oxford: Oxford University Press.

Dreyfus, H.L. (2014) 'Holism and Hermeneutics', in Skillful Coping: Essays on the Phenomenology of Everyday Perception and Action, M.A. Wrathall (ed.) Oxford: Oxford University Press.

Dworkin, R. (2002) Sovereign Virtue: The Theory and Practice of Equality, Cambridge, MA: Harvard University Press.

---- (2006) Is Democracy Possible Here? Princeton: Princeton University Press.

Fives, A. (2020) 'The Unnoticed Monism of Judith Shklar's Liberalism of Fear', Philosophy and Social Criticism 46 (1) 45-63.

Freeden, M. (1996) Ideologies and Political Theory: A Conceptual Approach, Oxford: Clarendon Press. 
---- (2005) Liberal Languages: Ideological Imaginations and Twentieth-Century Progressive Thought, Princeton: Princeton University Press.

(2008) 'European Liberalisms: An Essay in Comparative Political Thought', European Journal of Political Theory, 7 (1) 9-30.

---- (2009) 'Editorial: What Fails in Ideologies?' Journal of Political Ideologies, 14 (1) 1-9.

Gadamer, H.-G. (1981) 'Hermeneutics as Practical Philosophy', in Reason in the Age of Science, F.G. Lawrence (trans.) Cambridge, MA: The MIT Press.

----- (1989) Truth and Method, J. Weinsheimer and D.G. Marshall (trans.) New York: Crossroad, 2nd ed.

Galston, W.A. (1991) Liberal Purposes: Goods, Virtues, and Diversity in the Liberal State, New York: Cambridge University Press.

Gray, J. (2013) Isaiah Berlin: An Interpretation of His Thought, Princeton: Princeton University Press, new ed.

Hampshire, S. (1989) Innocence and Experience, London: Penguin Press.

Heidegger, M. (2008) 'The Way to Language', P.D. Hertz (trans.) in Basic Writings, D.F. Krell (ed.) New York: HarperCollins.

Hobhouse, L.T. (1964 [1911]) Liberalism, New York: Oxford University Press.

Honneth, A. (1995) The Struggle for Recognition: The Moral Grammar of Social Conflicts, Joel Anderson (trans.) Cambridge, MA: MIT Press.

Kymlicka, W. (1995) Multicultural Citizenship: A Liberal Theory of Minority Rights, Oxford: Oxford University Press.

----- and W. Norman (2000) 'Citizenship in Culturally Diverse Societies: Issues, Contexts, Concepts', in Kymlicka and Norman (eds.) Citizenship in Diverse Societies, Oxford: Oxford University Press.

---- (2002) Contemporary Political Philosophy: An Introduction, Oxford: Oxford University Press, 2nd ed.

Larmore, C. (1996) 'Political Liberalism', in Morals and Modernity, Cambridge: Cambridge University Press.

Lindsay, A.D. (1950) 'Introduction' to Thomas Hobbes, Leviathan, New York: E.P. Dutton \& Co. 
Merleau-Ponty, M. (2012) Phenomenology of Perception, D.A. Landes (trans.) New York: Routledge.

Misra, S. (2016) 'Doubt and Commitment: Justice and Skepticism in Judith Shklar's Thought' European Journal of Political Theory 15 (1) 77-96.

Namier, L. (1955) 'Human Nature in Politics', in Personalities and Powers, London: Hamish Hamilton.

Rawls, J. (1985) 'Justice as Fairness: Political not Metaphysical', Philosophy and Public Affairs, 14 (3) $223-51$.

----- (1999) A Theory of Justice, Cambridge, MA: Harvard University Press, rev. ed.

----- (2005) Political Liberalism, New York: Columbia University Press, exp. ed.

Raz, J. (1986) The Morality of Freedom, Oxford: Oxford University Press.

---- (1994) 'Liberalism, Scepticism, and Democracy', in Ethics in the Public Domain: Essays in the Morality of Law and Politics, Oxford: Oxford University Press.

Richardson, H.S. (1990) 'The Problem of Liberalism and the Good', in R.B. Douglass, G.M. Mara and H.S. Richardson (eds.) Liberalism and the Good, New York: Routledge.

Rorty, R. (1989) Contingency, Irony, and Solidarity, Cambridge, Cambridge University Press.

----- (1998) Achieving Our Country: Leftist Thought in Twentieth-Century America, Cambridge, MA: Harvard University Press.

Sandel, M. (1998) Liberalism and the Limits of Justice, Cambridge: Cambridge University Press, 2nd. ed.

---- (2005) 'The Procedural Republic and The Unencumbered Self', in Public Philosophy: Essays on Morality in Politics, Cambridge, MA: Harvard University Press.

Shklar, J.N. (1984) Ordinary Vices, Cambridge, MA: Harvard University Press.

---- (1986 [1964]) Legalism: Law, Morals, and Political Trials, Cambridge, MA: Harvard University Press, rev. ed.

---- (1998a) 'The Liberalism of Fear', in Political Thought and Political Thinkers, S. Hoffmann (ed.) Chicago: University of Chicago Press.

----- (1998b) 'The Work of Michael Walzer', in Political Thought and Political Thinkers, S. Hoffmann (ed.) Chicago: University of Chicago Press. 
Taylor, C. (1985) 'Atomism', in Philosophy and the Human Sciences: Philosophical Papers 2, Cambridge: Cambridge University Press.

----- (1988) 'The Hermeneutics of Conflict', in J. Tully (ed.) Meaning and Context: Quentin Skinner and His Critics, Cambridge: Polity Press, 1988.

---- (1995a) 'Cross-Purposes: The Liberal-Communitarian Debate', in Philosophical Arguments, Cambridge, MA: Harvard University Press.

---- (1995b) 'The Politics of Recognition', in Philosophical Arguments, Cambridge, MA: Harvard University Press.

----- (2007) A Secular Age, Cambridge, MA: Harvard University Press.

Walzer, M. (1983) Spheres of Justice: A Defense of Pluralism and Equality, New York: Basic Books.

---- (2007a) 'Liberalism and the Art of Separation', in Thinking Politically: Essays in Political Theory, D. Miller (ed.) New Haven: Yale University Press.

---- (2007b) 'Political Action: The Problem of Dirty Hands', in Thinking Politically: Essays in Political Theory, D. Miller (ed.) New Haven: Yale University Press.

Williams, B. (1981) 'Politics and Moral Character', in Moral Luck: Philosophical Papers 19731980, Cambridge: Cambridge University Press. 